\title{
АССОЦИАЦИЯ ГЕНЕТИЧЕСКИХ ФАКТОРОВ С РАЗВИТИЕМ НАРУШЕНИЙ УГЛЕВОДНОГО ОБМЕНА У МОЛОДЫХ ПАЦИЕНТОВ С МЕТАБОЛИЧЕСКИМ СИНДРОМОМ
}

\author{
${ }^{1}$ Корнеева Е.В., ${ }^{2}$ Воевода М.И., ${ }^{2}$ Семаев С.Е., ${ }^{2}$ Максимов В.Н. \\ 'БУ ХМАО-Югры «Сургутский государственный университет», Сургут \\ ${ }^{2}$ НИИ терапии и профилактической медицины — филиал ФГБНУ «Федеральный исследовательский центр \\ Институт цитологии и генетики СО РАН», Новосибирск
}

ЦЕЛЬ: изучить роль полиморфизма rs7903146 гена TCF7L2 u rs1801133 (С677T) гена MTHFR в развитии нарушений углеводного обмена у молодых пациентов с метаболическим синдромом (MC).

МАТЕРИАЛЫ И МЕТОДЫ: обследовано 835 человек в возрасте 18-44 лет, из них контрольная группа - 134, с MC - 701 человек. Некоренные жители $(\mathrm{n}=569)$ представлены городским и сельским населением, из них с МС - 472, без MC - 97 человек. Коренное малочисленное население севера (КМНC) 266 ханты, из них МС - 229, 37 - без метаболических нарушений. Геномную ДНК выделяли из венозной крови методом фенол-хлороформной экстракции, применив ПЦР с ПДРФ. Все пациенты подписали информированное согласие на участие в исследовании.

РЕЗУЛЬТАТЫ: при анализе распределения частот генотипов и аллелей полиморфного маркера rs7903146 гена TCF7L2 среди молодых жителей Севера нами не было выявлено статистически значимых различий между группами. Мутантный аллель Т встречался у 21,9\% участников исследования (у 22,3\% некоренных жителей и 20,9\% хантов). Распределение генотипов и аллелей rs 1801133 (C677T) гена MTHFR среди обследованных коренных и некоренных жителей: носители генотипа СС составили 52,6\%, СТ - 37,4\%, ТT - 10\%. Носительство аллеля Т было отмечено у 28,7\% всех обследованных, при этом среди некоренных и коренных жителей по частоте носительства аллеля Т достоверных различий не выявлено - $29,1 \%$ и 27,6\%. В обследуемой когорте пациентов с MC мутантный аллель T rs7903146 гена TCF7L2 встречался чаще у пациентов с ИР (23,2\%, ОШ $1,146,95 \%$ ДИ 0,872-1,505, p=0.026). При этом носителей данного аллеля среди коренного населения с МС и ИР (26,8\%, ОШ 1,676, $95 \%$ ДИ 0,412-1,286, p=0.048) было больше, чем среди некоренного населения (22,0\%, ОШ 0,968, 95\% ДИ 0.699-1.341, p=0.023) и среди хантов с МС, но без гипергликемии (17,9\%, ОШ 1,011,95\% ДИ 1,016-2,764, p=0,051). Шанс развития нарушения толерантности к глюкозе и СД у 8,9\% носителей гомозиготного генотипа ТТ у хантов (ОШ 2.325, 95\% ДИ 0.707-7.641, $\mathrm{p}=0.006$ ) превышает таковой в целом обследуемой когорте (ОШ 1,443, 95\% дИ 0,757-2,750, $\mathrm{p}=0.042$ ). Распространенность гомозиготного генотипа ТТ среди мужчин с МС с гипергликемией составила 9,5\%, среди женщин - 6,7\%. Доля гомозиготных генотипов СС и гетерозиготного СТ в сравниваемых группах не различалась. Доля носителей мутантного аллеля Т среди мужского населения встречалось больше, чем среди женского населения (у мужчин - ОШ 1,041, 95\% ДИ 0.642-1.688, p=0.015; у женщин — ОШ $1.251,0.898-1.743 ; p=0.021)$. Частота носительства аллеля T rs1801133 (С677T) гена MTHFR среди коренных и некоренных лиц с МС с гипергликемией - 27,8\%. По гендерному признаку значимых отличий по встречаемости минорного аллеля Т нами не было выявлено. Хотя среди мужчин с МС и гипергликемией данный аллель встречался в 25,4\% случаев выше, чем среди женщин (22,3\%).У мужчин коренной этнической группы носителей генотипа TT гена MTHFR были обнаружена тенденция к повышению шансов развития гипергликемии (ОШ 21,600, 95\% ДИ 1,654-290,10, p=0,031).

Таким образом, лица с МС и носители исследуемого гена имеют генетическую предрасположенность к дисфункции $\beta$-клеток поджелудочной железы и развитию СД. Оценка генетических маркеров поможет выявить группы людей с риском развития СД и своевременному принятию профилактических мер по развитию метаболических нарушений.

КЛЮЧЕВЫЕ СЛОВА: метаболическИй синдром; сахарный диабет; полиморфизм rs7903146 гена TCF7L2 и rs1801133 (C677T) гена MTHFR; гипергликемия. 